

\section{The Impact of Housing Loans on Economic Growth in Turkey: Times Series Analysis for 2010-2015 Period}

\author{
Gülay Selvi Hanişoğlu \\ Özlem Arzu Azer
}

\section{Introduction}

Wherever you are in the world, housing is one of the basic needs of human being. In addition to being a basic need for human being, it also functions as an important investment tool for people. Dwelling place or housing is one of the biggest assets which people invest in their lifetimes. For instance, in the United States, real estate accounts for roughly a third of the total assets held by the nonfinancial private sector. (Min Zhu, 2014)

Housing sector is also essential and crucial for the whole economy. Housing construction sector is considered a prime source of employment generation and offers job opportunities to skilled, semi-skilled and unskilled workers. Housing construction sector together with other type of building constructions play a crucial role in generating income. Housing sector has strong links with other economic sectors and also affect other sectors with the multiplier effect such as financial sector, construction sector, furniture sector, paint industry and retail industry.

As being a part of financial markets, mortgage markets and mortgage loans are important tools of monetary policy. If housing sector works properly in the economy, the overall economy will be well-functioning and healthy. And vice versa also true, as economies develop, the housing markets will be growing and deepening. The mortgage markets are an important instrument of monetary policy. As targeting healthier economies, governments make and review regulations regarding mortgage markets.

In our paper, the relation between economic growth and housing loans will be analyzed in Turkey for the 2010-2015 period. Firstly, the history and improvements in Turkish economy will be summarized and improvements for housing loan market will be followed. This paper mainly consists two sections. In the first section, general outlook of Turkish economy and economic growth data are analyzed. In the second section, housing loans and regulations on the housing sector are examined in detail.

\section{Literature Review}

There are many studies analyzing the role of housing sector on economic growth and investigating the relationship between housing sector and economic growth. In literature, there are different approaches; some of them analyze the effect of economic growth on different sectors or financial products such as different type of loans or securities markets. Other types of studies analyze the topic from the industrial side and investigate the effect of different sectors on the economic growth of countries.

Ünalmış (2002) inquires the direction of causality between the financial development and economic growth for Turkey for the period of 19702001. The results show that, financial development significantly causes economic growth in the short-run, and in the long-run, there is a bidirectional relationship between financial development and economic growth. Another study done by Alhowaish (2015) shows that there is a relationship between the construction sector and economic growth in Saudi Arabia. This study empirically investigates the relationship between construction flow and economic growth for Saudi Arabia during the 1970-2011 period. The World Bank (1984) states that, the importance of the construction industry stems from its strong linkages with other sectors of the economy.

Analysis of Macroeconomic Aspects of Financial Development and Economic Growth published by Tsuru (2000) summarizes some theoretical considerations of the topic and also reviews the empirical literature. The role of financial development in economic growth is described at the macro level, both theoretically and empirically. The study of King and Levine (1993) is emphasized by Tsuru as an comprehensive empirical research. Jappelli and Pagano (1994), focusing on household credit markets, found that their development (represented, for example, by the ratio of consumer credit to GDP) was negatively correlated with savings and growth rates and that some types of financial development could affect growth rates negatively, as predicted by theoretical models (Tsuru,2000). Although in a pure neoclassical framework the financial system is irrelevant to economic growth in practice, an efficient financial system can simultaneously lower the cost of external borrowing, raise the returns to savers, and ensure that savings are allocated in priority to projects that promise the highest returns, all of which have the potential of affecting economic growth rates. The empirical literature reviewed above shows that, there seems to be a causal link between the level of financial development and the rate of accumulation of capital, or of multifactor productivity. Even though an efficient financial system can (and apparently does) reduce the 
level of household savings, by easing access to consumer credit, the welfare implications remain positive, unless there is a significant gap between private and social time discount rates (Tsuru,2000).

\section{Economic Growth}

Economic growth in Turkey shows a steady performance since 2000's. After 2012, there are some concerns about sustainability of this growth performance. There are wars across the southern border, and severe domestic tensions in the Eastern regions. Trade restrictions with Russia, inflow of millions of refugees and decreasing trend tourism income caused negative effects on growth figures. Growth figures in Turkey remains centered on the domestic demand and is funded by capital inflows which increase the foreign debt figures of country.

In this section, firstly the economic growth figures of Turkey have been analyzed through years. In our paper, Gross Domestic Product (GDP) is used as the main indicator of economic growth. The following tables summarize the Gross Domestic Product figures for the years under investigation. Percentage changes in GDP figures are also shown. The following tables also show GDP (Gross Domestic Product) figures with the expenditure approach for 1998-2015.

Table 1: GDP (Gross Domestic Product) for 19982015 (TL, bio)

\begin{tabular}{|c|c|c|c|c|c|c|c|c|c|c|c|c|c|c|c|c|c|c|}
\hline Years & 1998 & 1999 & 2000 & 2001 & 2002 & 2003 & 2004 & 2005 & 2006 & 2007 & 2008 & 2009 & 2010 & 2011 & 2012 & 2013 & 2014 & 2015 \\
\hline Index & 71,07 & 68,66 & 73,22 & 68,85 & 73,28 & 77,30 & 84,85 & 9250 & 99,07 & 104,06 & 104,94 & 100,0 & 108,49 & 120,54 & 120,32 & 137,04 & 14,12 & 1528,80 \\
\hline $\begin{array}{l}\text { Volume } \\
\text { Billion TL }\end{array}$ & 710 & 686 & 732 & 6880 & 732 & 773 & 848 & 924 & 990 & 1040 & 1009 & 99 & 1.084 & 1.204 & 1262 & 1.399 & $|140|$ & 1.527 \\
\hline
\end{tabular}

Source: TUİK

Table 2: GDP changes for 1998-2015 (\%)

\begin{tabular}{|c|c|c|c|c|c|c|c|c|c|c|c|c|c|c|c|c|c|c|}
\hline Years & 1998 & 1999 & 2000 & 2001 & 2002 & 2003 & 2004 & 2005 & 2006 & 2007 & 2008 & 2009 & 2010 & 2011 & 2012 & 2013 & 2014 & 2015 \\
\hline $\begin{array}{c}\text { Change } \\
\text { compared to } \\
\text { previous year }\end{array}$ & - & $-3,39$ & 6,64 & $-5,56$ & 6,43 & 5,61 & 9,64 & 9,01 & 7,11 & 5,03 & 0,85 & $-4,70$ & 8,49 & 11,11 & 4,79 & 8,49 & 5,17 & 6,06 \\
\hline
\end{tabular}

Source: TUIK

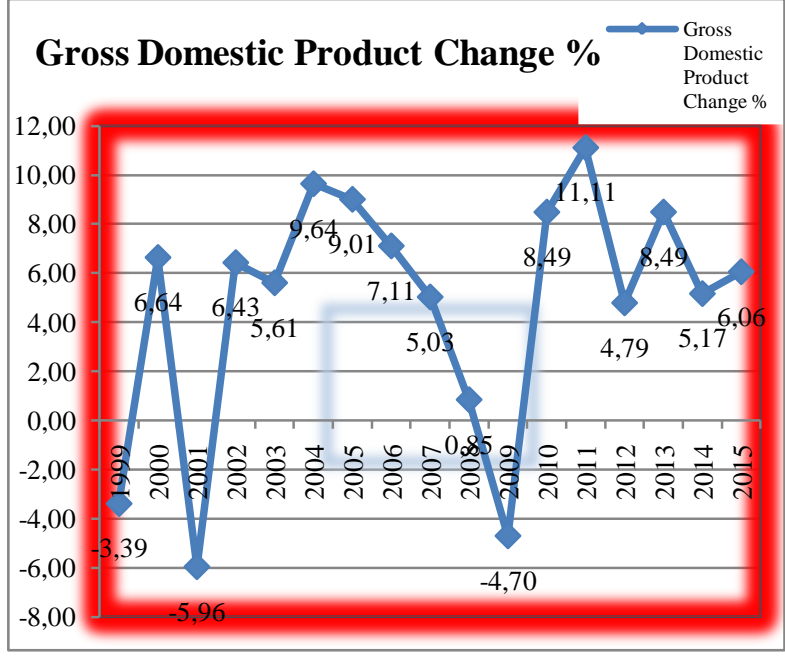

Figure 1. Gross Domestic Product Change (\%) for 1999- 2015 Period

It can be seen from the above figure that, 20002001 and 2007-2008 economic crises made a negative effect on the economic growth of Turkey and there were sharp declines at these periods.

Table 3: The Growth Rate at Selected Sectors in Turkish Economy

\begin{tabular}{|c|c|c|c|c|c|}
\hline \multicolumn{6}{|c|}{$\begin{array}{l}\text { Growth rate in selected sectors (Gross Domestic Product in chain linked } \\
\text { volume, index and percentage change }(2009=100) \text {, by kind of econ.activity) }\end{array}$} \\
\hline & $\begin{array}{l}\text { Agriculture, } \\
\text { forestry and } \\
\text { fishing }\end{array}$ & Manifacturing & Construction & $\begin{array}{l}\text { Real } \\
\text { Estate } \\
\text { Activities }\end{array}$ & $\begin{array}{l}\text { GDP } \\
\text { (purchas } \\
\text { er's } \\
\text { price) }\end{array}$ \\
\hline \multicolumn{6}{|l|}{1998} \\
\hline 1999 & $-4,56$ & $-5,54$ & $-3,7$ & 4,68 & $-3,39$ \\
\hline 2000 & 6,41 & 7,06 & 6,39 & 5,21 & 6,64 \\
\hline 2001 & $-8,89$ & $-8,89$ & $-20,35$ & 1,36 & $-5,96$ \\
\hline 2002 & 8,68 & 4,01 & 17,73 & 3,72 & 6,43 \\
\hline 2003 & $-1,53$ & 9,8 & 13,8 & 1,39 & 5,61 \\
\hline 2004 & 3,95 & 13,24 & 21,32 & 2,45 & 9,64 \\
\hline 2005 & 7,93 & 9,63 & 14,98 & 2,3 & 9,01 \\
\hline 2006 & 1,55 & 9,83 & 25,56 & 1,22 & 7,11 \\
\hline 2007 & $-6,22$ & 6,75 & 10,57 & 0,82 & 5,03 \\
\hline 2008 & 4,53 & 0,5 & $-4,65$ & 0,35 & 0,85 \\
\hline 2009 & 4,13 & $-8,89$ & $-15,87$ & $-0,16$ & $-4,7$ \\
\hline 2010 & 7,67 & 9,6 & 17,14 & 4,47 & 8,49 \\
\hline 2011 & 3,44 & 20,02 & 24,74 & 4,96 & 11,11 \\
\hline 2012 & 2,2 & 2,26 & 8,28 & 4,29 & 4,79 \\
\hline 2013 & 2,32 & 9,31 & 14,03 & 2,92 & 8,49 \\
\hline 2014 & 0,59 & 6,1 & 5 & 2,53 & 5,17 \\
\hline 2015 & 9,12 & 5,86 & 4,9 & 2,39 & 6,06 \\
\hline
\end{tabular}

Source: TUIK database,

http://www.tuik.gov.tr/UstMenu.do?metod=temelist

\section{The Share of Construction Sector in GDP}

In Turkey, economic growth and construction sector figures always move together. It means if the economic growth figures are improving, construction sector is improving. If the economic growth figures are contracting, the construction sector figures are also contracting. But generally volume of contracting in the construction sector is higher than the economic 
contraction figures and in the improvement periods, the figures of improving in the construction sector are higher than the total economic growth figures. This connection indicates two results. Firstly, economic booming or contracting periods match fully, which shows a close relationship with economic growth and construction sector. Secondly, for crises periods, construction sector would be the leading sector for other sectors that can easily stimulate economic growth.

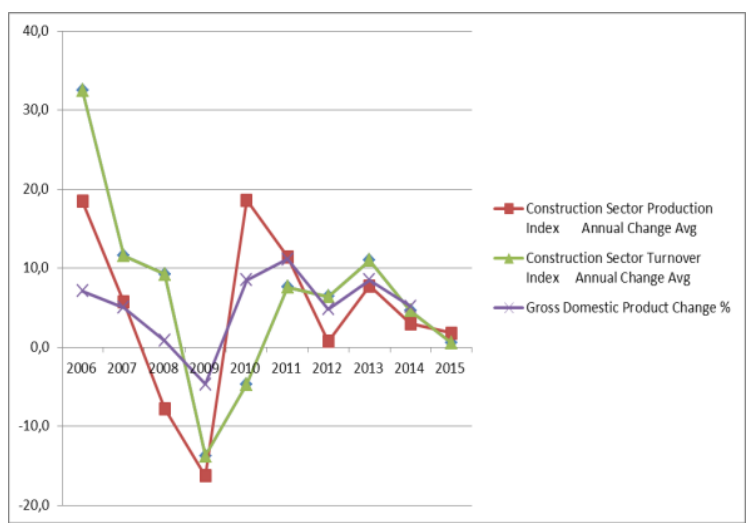

Figure 2. Comparison between Gross Domestic Product Change and Construction Sector Production and Turnover Change (\%) for 2006- 2015 period Source: TUIK Database

Turkish authorities are aware of this relationship and have made different types of supports to construction sector as well as the financial sector for increasing supply and demand of construction sector. The construction industry usually accounts for between 3 percent to 8 percent of a developing country's gross domestic product (GDP); the more dynamic national economies as well as wealthier countries are largely bunched at the upper end of this range (The Construction Industry:Issues and Strategies in Developing Countries, 1984).

Construction sector contributes to GDP growth, employment and construction materials industry. Housing construction has backward and forward linkages for the economy and affects durable consumer goods or the furniture sector. The growing interest of many countries in developing their construction industry has coincided with increasing concern of banks for this sector (The Construction Industry:Issues and Strategies in Developing Countries, 1984).

Construction sector has a leading role for stimulating economic activity and improving job opportunities in Turkey. Construction sector also plays an important role in the economic growth of Turkey. Furthermore, it has a crucial effect in the GNP growth.

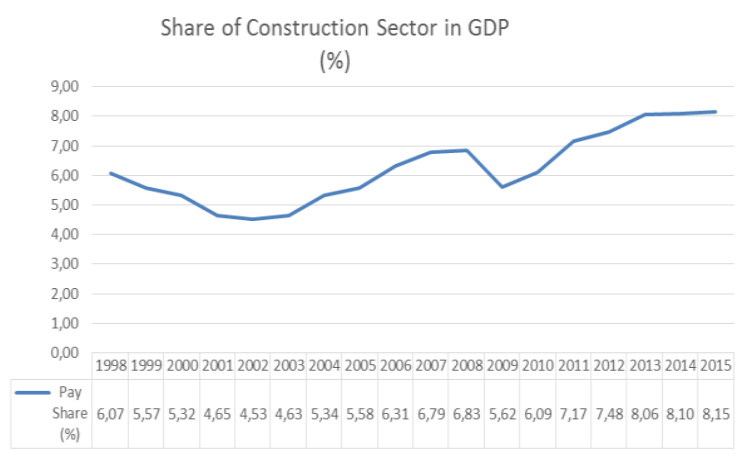

Figure 3. Share of Construction Sector in GDP Source: TUIK database, http://www.tuik.gov.tr/UstMenu.do?metod=temelist

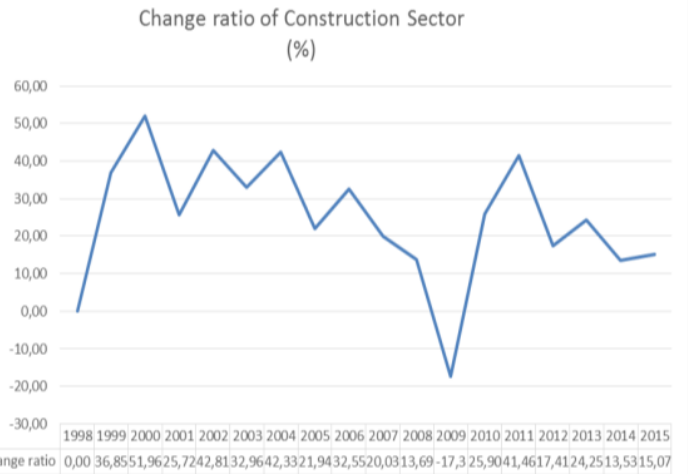

Figure 4. Change Ratio of Construction Sector

Source: TUIK database

http://www.tuik.gov.tr/UstMenu.do?metod=temelist

As seen in the figure above, the share of construction sector has increased through years. The share of construction sector had increased from 5,32 \% in 2000 to 8,15 \% in 2015. Due to 2008 economic crisis, a deep decrease of $17,39 \%$ had occurred in 2009. The highest growth rate of 41,46\% had occurred in 2011 parallel to the economic growth.

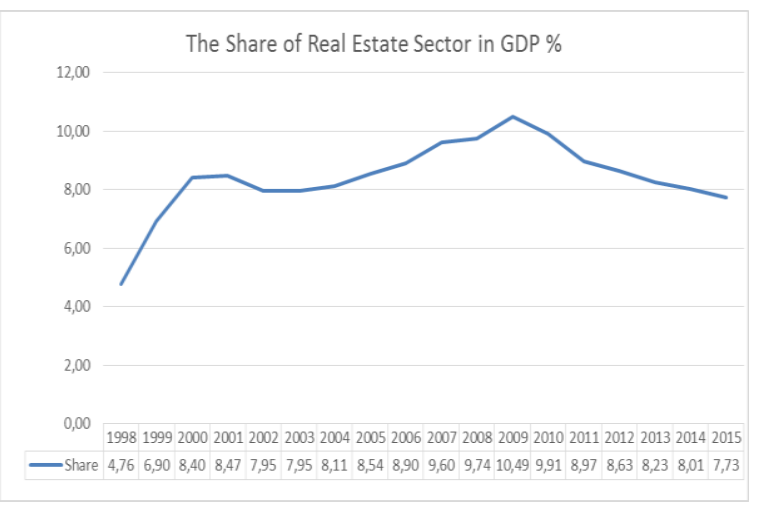

Figure 5. Share of Real Estate Activities in GDP Source: TUIKK database,

http://www.tuik.gov.tr/UstMenu.do?metod=temelist 
Average share of real estate activities in GDP had occurred as 8,7 while the growth rate had occurred as $10,30 \%$ in 2015. It is also important to mention the effect of sector over employment. Its share in employment had been 7,2 \% in 2015. The employment in construction sector was realized as 1.914.000 in 2015.

It is seen very clearly that, the construction and real estate sectors play a very important role in Turkish economy. In the last 10 years, new infrastructure projects have increased in Turkey. Urban transformation is one of the reasons of the sector improvement. The construction sector is also important in the improvement of related sectors. Increase in the construction sector provides improvement in cement, ceramic, lighting and insulation.

Turkey has also become a very important country in international construction. Turkish contractor sector improved and the undertaking contracts reached to 342 bio.USD in 115 countries since 1972 (Republic of Turkey Ministry of Economy).

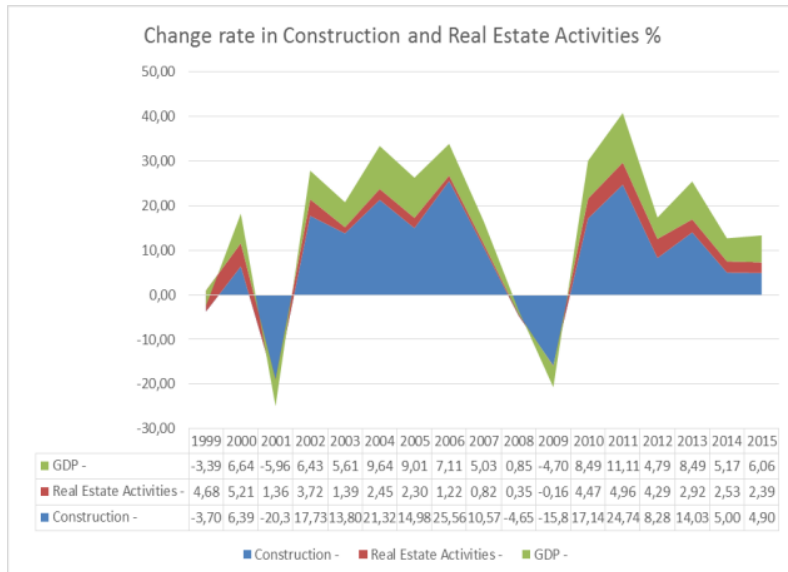

Figure 6. Change Rate in Construction Sector and Real Estate Activities

Source: TUIK database,

http://www.tuik.gov.tr/UstMenu.do?metod=temelist

Construction sector and the real estate sector are very sensitive to economic growth and expectations. After 2001 and 2008 crises, construction sector showed a sharp improvement. It is seen very clearly that, construction sector moves parallel to economic growth. In 2009, growth of sector reversed due to 2008 global crisis. In a similar way, the highest growth realized in 2011 is pretty parallel to economic growth.

\section{The Relationship Between Housing Loans and Economic Growth}

Turkey has been facing house shortage since the urbanization starts with the effect of industrialization around 1950's. Migration began from rural areas to cities and this brought housing problem in big cities both in qualitative and quantitative aspects. Around 1980's, some measurements had been taken for solving the housing problem.

In some countries, there are advanced funding methods for people to buy homes. Concerning Turkey as a developing country before 1980, money had to be saved before buying a home. There were no any advanced funding mechanisms. After 1980, Turkish governments took some measurements for supporting the housing sector. The Housing Development Administration of Turkey (TOKİ-Toplu Konut İdaresi Başkanlığı) and Housing Development Fund was established. Mass housing projects also started with the initiative of Emlak Bank (Türkiye Emlak Bankası). At this period, remarkable improvements were observed in the housing sector. But, the lack of efficient housing loan system was a very important problem. Economic problems in the late 90's and crises in Turkey in 2001's made a negative effect on housing sector. After crises, structural reforms were implemented and banking sector was rehabilated. Banking sector increased the share of credits in their portfolio and also decreased the funding rate borrowing from outside.

\section{The Real Estate Sector and Financing Methods}

There are some different methods of housing finance: Finance by construction firm or mortgaged loans. As an important housing financing method, mortgage loans are very sensitive to the interest rate and uncertainty. People who want to buy a house carry some different purposes as owning a house to live or making an investment. Especially, if the purpose is investment, sensitivity to interest rate is at a high level. Uncertainty is another important factor for decision to buy house. If there is uncertainty in the market, people prefer to wait. However, the ratio of housing loans to GDP increased from 2,31 \% in 2006 to 9,81 \% in 2015. The reason of this increase is widening from requirement of structural transformation to increasing requirement of housing due to increased population as well as changing life styles.

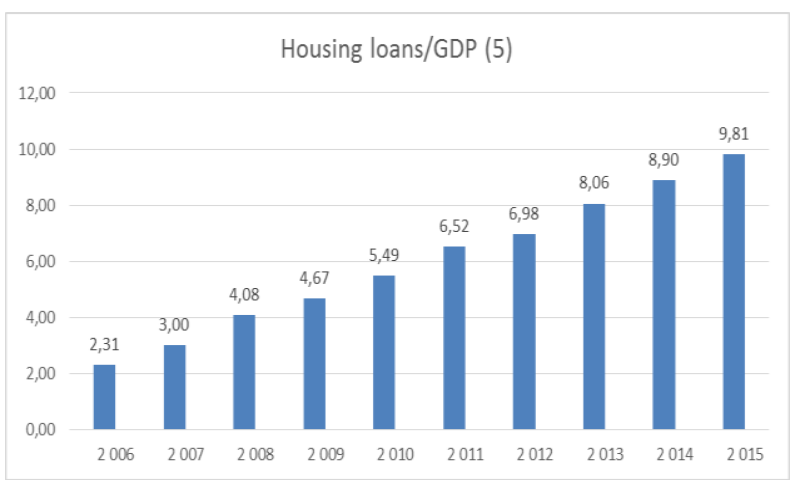

Figure 7. Housing Loans to GDP (2006-2015)

Source: TCMB, http://evds.tcmb.gov.tr/ 
Parallel to the increase in construction sector, real estate market also accelerated in Turkey. Figure 7 shows the increase in housing sales by the finance method. Housing finance methods are mortgage sales and other methods which include construction firms' finance facilities and cash payment. Through 2010-2017, other housing finance methods also increased while mortgage finance fluctuated by years. Other finance methods increased from 360.357 in 2010, to 891.945 in 2016 by $147 \%$. Mortgage finance method increased from 246.741 in 2010 to 449.508 in 2016 by $82 \%$. It seems that other finance methods are preferable to the mortgage finance method.

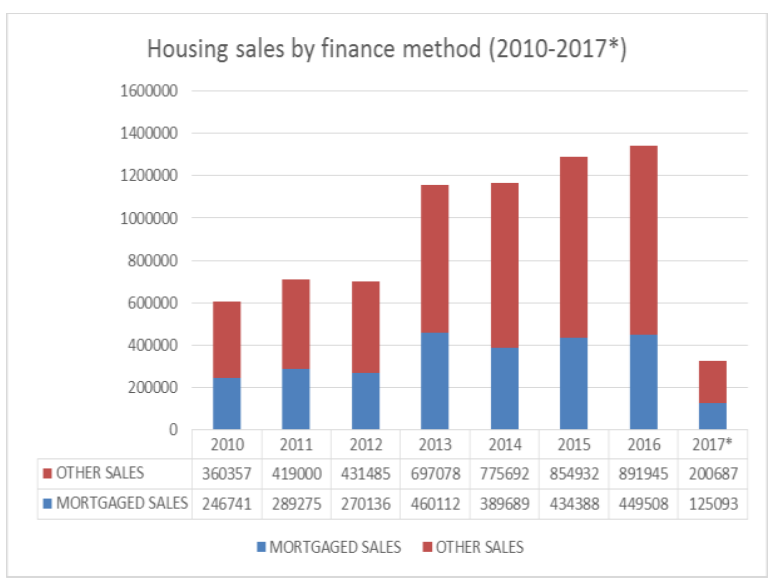

Figure 8. Housing Sales by the Financing Method (2010-2017*)

Source: TUIK database, General Directorate of Land Registry and Cadastre (2017, January, February and March)

In Turkey, the share of housing loans in individual loans has increased by years. Figure 8 shows this increase as value, while Figure 9 shows this increase as percentage.

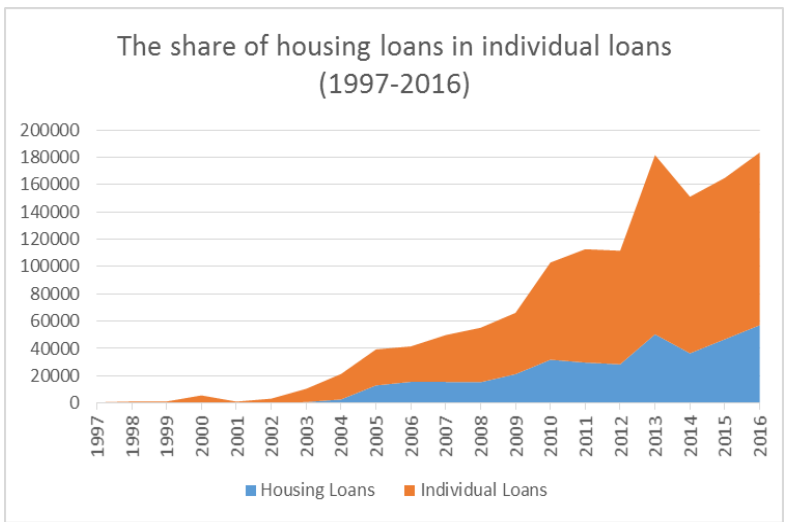

Figure 9. The Share of Housing Loans in Individual Loans (2005-2017*)

Source: TCMB, http://evds.tcmb.gov.tr/
The share of mortgage housing loans in individual loans has increased by years. The share in individual loans increased by $43,9 \%$ in 2005 to $47,72 \%$ in 2017.

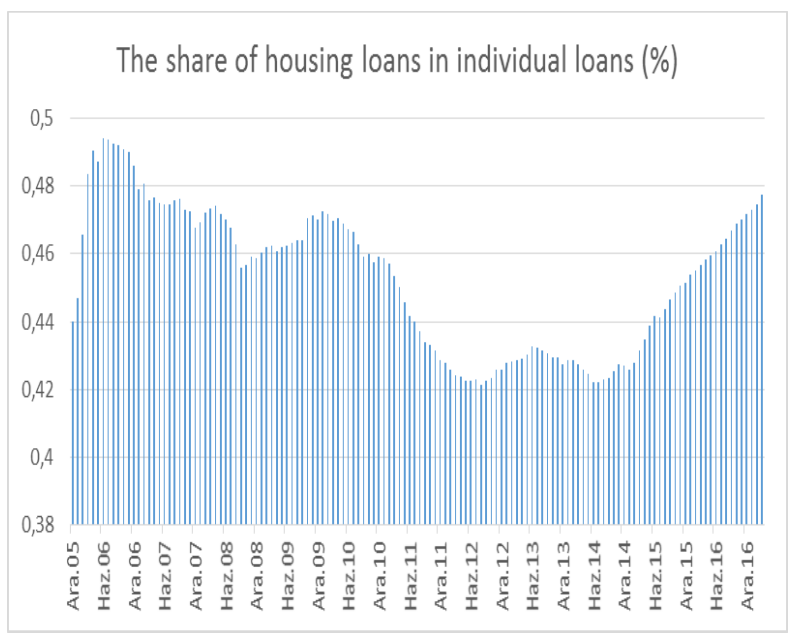

Figure 10. The Share of Housing Loans in Individual Loans (\%)

Source: TCMB, http://evds.tcmb.gov.tr/

Increase in the interest rates by CBTA affects the consumer confidence very sharply. It shows that there is a very strong and close relationship between house buying and housing loans' interest rate. Figure 10 shows the interest rate trend since 2002 and it is seen that housing loans' interest rate trend is downward.

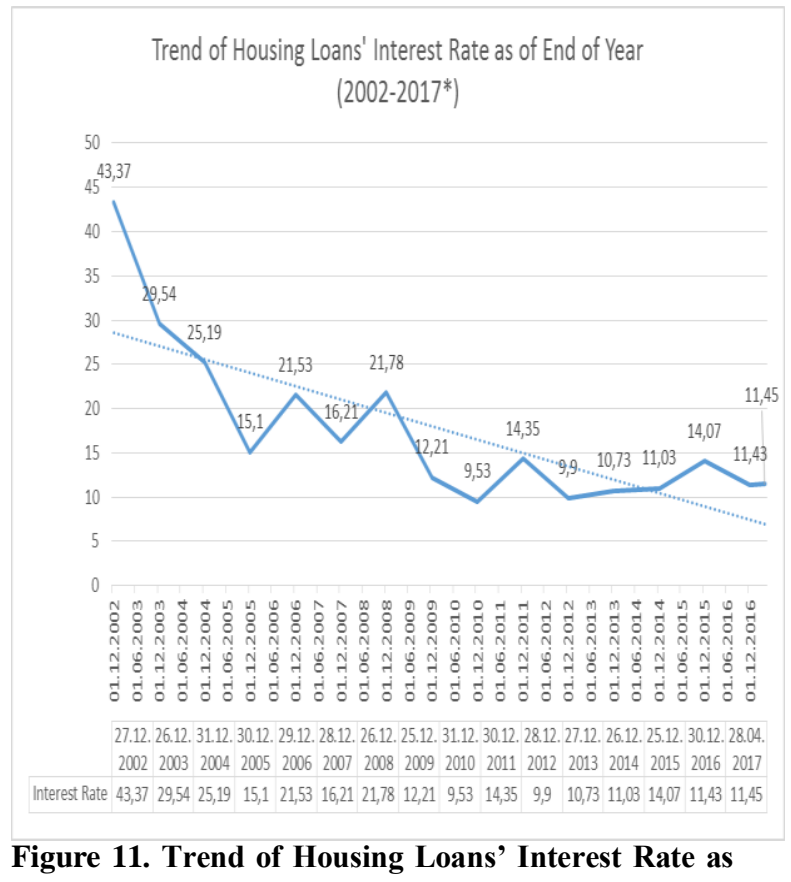
of End of Year (2002-2017*)

Source: TCMB, http://evds.tcmb.gov.tr/ 


\section{Conclusion}

Economic theory, empirical studies and policy makers have emphasized the economic significance of the construction sector to national output. There are various types of construction types. Our paper focuses on the residential type of construction activity due to high share in the total construction activity. Housing demand, which is the basic human need, requires large amount of savings and borrowings. Economic growth, stable economic environment, improving credit facilities will have a positive impact on housing demand in Turkey. Demand for housing will continue for the following years due to young population of Turkey and changing lifestyles.

In Turkey, economic growth and construction sector figures always move together. It means if the economic growth figures are improving, construction sectors also improve and if the economic growth figures are contracting, the construction sector figures also contract. Economic growth, stable economic environment and improving credit facilities will have a positive impact on the housing demand. There is also a close relationship between the construction sector and economic Growth in Turkey.

There were no advanced funding mechanisms before 1980's in Turkey. After 2000, structural reforms were implemented and banking sector was rehabilated.. The share of housing loans increased in the banking sector portfolio. Analyzing the housing sales by finance methods through 2010- 2015 shows that, the share of other finance methods is higher than housing loans and mortgage loans. So, other finance methods including cash payment are more preferable than housing loans and mortgage loans.

\section{REFERENCES}

Alhowaish,A.K.,(2015). Causality between the Construction Sector and Economic Growth: The Case of Saudi Arabia, International Real Estate Review . Vol. 18 No. 1: pp. $131-147$.

Emlak Konut Gayrimenkul Yatırım Ortaklığı A.Ş.(2016). Gayrimenkul ve Konut Sektörüne Bakış.

IMF Conference Paper, (2014). Housing Markets, Financial Stability and the Economy. Min Zhu, Deputy Managing Director, IMF.
Kar,M.,Pentecost,E.J.,(2000). $\quad$ Financial Development and Economic Growth in Turkey: Further Evidence on Causulty Issue, Economic Reserch Paper No: 00/27 Loughborough University.

Karg1,B., (2013). Housing Market and Economic Growth Relation:Time Series Analysis Over Turkey (20002012)Volume: 10 Issue: 1 Year: 2013 International Journal of Human Sciences ISSN:1303-5134.

Shahini,I., (2014). How is Mortgage Lending Influencing the Economic Growth in Albenia, International Journal of Science and Engineering Applications, Volume 3 Issue 4, 2014. ISSN-23197560 (online).

Stratejik Düşünce Enstitüsü,(2014). Türkiye Konut Sektörü Raporu.

The World Bank (1984). The Construction Industry:Issues and Strategies in Developing Countries. Washington,D.C.

Topaloğlu,M,(2012). An Evaluation of Turkish Mortgage System From the Perspective of Global Economic Crises, China US Business Review,ISSN 1537-1514, July 2012 Vol. 11, No.7,886-895.

TCMB Database

TUIK Database

Tsuru, K (2000), "Finance and Growth: Some Theoretical Considerations, and a Review of the Empirical Literature" Economics Department Working Papers, OECD, January, No.228.

Ünalmıș ， D., (June 2002),The Causality Between Financial Development And Economic Growth: The Case Of Turkey, The Central Bank of the Republic of Turkey, Research Department Working Paper No:3.

Yılmaz. C.,(2014). Banka Kredileri ve Büyüme İlişkisi-21-22 Mart 2014 tarihli Üretim Ekonomisi Kongresi. 